\title{
Cell therapy for full-thickness wounds: are fetal dermal cells a potential source?
}

\author{
J. J. Akershoek ${ }^{1}$ - M. Vlig ${ }^{2}$ - W. Talhout ${ }^{1,3} \cdot$ B. K. H. L. Boekema ${ }^{2}$ C. D. Richters ${ }^{4}$. \\ R. H. J. Beelen ${ }^{3}$ - K. M. Brouwer ${ }^{1}$ - E. Middelkoop ${ }^{1,2} \cdot$ M. M. W. Ulrich ${ }^{2,3}$
}

Received: 4 February 2015 / Accepted: 3 September 2015 /Published online: 9 October 2015

(C) The Author(s) 2015. This article is published with open access at Springerlink.com

\begin{abstract}
The application of autologous dermal fibroblasts has been shown to improve burn wound healing. However, a major hurdle is the availability of sufficient healthy skin as a cell source. We investigated fetal dermal cells as an alternative source for cell-based therapy for skin regeneration. Human $(\mathrm{hFF})$, porcine fetal (pFF) or autologous dermal fibroblasts (AF) were seeded in a collagen-elastin substitute (Novomaix, NVM), which was applied in combination with an autologous split thickness skin graft (STSG) to evaluate the effects of these cells on wound healing in a porcine excisional wound model. Transplantation of wounds with NVM+hFF showed an increased influx of inflammatory cells (e.g., neutrophils, macrophages, $\mathrm{CD}^{+}$and $\mathrm{CD} 8^{+}$lymphocytes) compared to STSG, acellular NVM (Acell-NVM) and NVM+AF at postsurgery days 7 and/or 14 . Wounds treated with $\mathrm{NVM}+\mathrm{pFF}$ presented only an increase in $\mathrm{CD} 8^{+}$lymphocyte influx. Furthermore, reduced alpha-smooth muscle actin ( $\alpha \mathrm{SMA})$ expression in wound areas and reduced contraction of the wounds was observed with NVM+AF compared to AcellNVM. Xenogeneic transplantation of NVM+hFF increased $\alpha \mathrm{SMA}$ expression in wounds compared to NVM+AF. An improved scar quality was observed for wounds treated with
\end{abstract}

M. M. W. Ulrich

mulrich@burns.nl

1 Department of Plastic, Reconstructive and Hand Surgery, Research Institute MOVE, VU University Medical Center, Amsterdam, The Netherlands

2 Association of Dutch Burn Centres, Zeestraat 27-29, 1941 AJ Beverwijk, The Netherlands

3 Department of Molecular Cell Biology and Immunology, VU University Medical Center, Amsterdam, The Netherlands

4 Euro Tissue Bank, Beverwijk, The Netherlands
$\mathrm{NVM}+\mathrm{AF}$ compared to Acell-NVM, NVM+hFF and NVM+ $\mathrm{pFF}$ at day 56. In conclusion, application of autologous fibroblasts improved the overall outcome of wound healing in comparison to fetal dermal cells and Acell-NVM, whereas application of fetal dermal fibroblasts in NVM did not improve wound healing of full-thickness wounds in a porcine model. Although human fetal dermal cells demonstrated an increased immune response, this did not seem to affect scar quality.

Keywords Fetal fibroblasts · Mesenchymal stem cells · Allogeneic/xenogeneic transplantation · Full-thickness wounds $\cdot$ Dermal substitutes

\section{Introduction}

Deep partial and full-thickness burn wounds often result in hypertrophic scars. Although burn wound care has improved over the years, scarless wound healing is still beyond reach. One of the causes that lead to hypertrophic scarring of burn wounds is partial or complete loss of the dermis. The use of collagen-based dermal substitutes to replace the lost and/or damaged dermis has been shown to improve the outcome of wound healing. Examples of this have been described by Bloemen et al. (2010) and Ryssel et al. (2008), who showed that transplantation of acellular collagen-based dermal substitutes with split thickness skin grafts (STSG) on top of fullthickness burn wounds improved scar quality. A smoother skin (less relief) and better pliability were observed, even 12 years post-surgery, compared to the control which received only STSG (Bloemen et al. 2010). Despite improved scar quality when using acellular dermal substitutes, the optimal result of full skin regeneration is still not achieved. Cell-based therapy is one of the strategies that may further improve skin 
regeneration. Indications for this have been found in the use of autologous dermal cells which were shown to improve the wound healing and/or scar formation of burn wounds. Lamme et al. (2000) demonstrated in a porcine full-thickness wound model that addition of autologous dermal cells to a dermal substitute can reduce scarring in vivo, as improved scar quality in terms of reduced redness, contraction and relief was observed compared to the acellular dermal substitute. Furthermore, dermal substitutes seeded with autologous dermal cells also significantly reduced alpha smooth muscle actin $(\alpha$ SMA $)$ expression in the wound area compared to acellular dermal substitutes. Expression of $\alpha$ SMA is indicative of the presence of myofibroblasts and contraction in scar tissue of burn wounds. Improved healing of burn wounds after application of substitutes containing autologous dermal cells was also shown clinically in a case report by Wisser and Steffes (2003).

In contrast to allogeneic cells, the advantage of using autologous cells is that they will not elicit a host versus graft (rejection) reaction upon transplantation. On the other hand, one of the major hurdles with autologous cell-based therapies is to obtain sufficient cells in a limited amount of time. Especially, patients with extensive burn wounds have limited availability of healthy skin for harvesting autologous dermal cells. Moreover, expansion of the autologous cells to a sufficient number may take up to 3 weeks (Hata 2007; Tan et al. 2014) and is associated with high costs. To overcome these hurdles, an alternative cell source is sought for use in cell-based therapies. One of the cell types that has been proposed are mesenchymal stem cells (MSCs). MSCs are known for their multipotency (Dominici et al. 2006; Maxson et al. 2012). It has been reported that direct transplantation of MSCs, or seeded in dermal substitutes, can have beneficial effects on wound healing in vitro and in vivo (Laverdet et al. 2014; Maxson et al. 2012). An in vivo animal study by Liu et al. (2008) showed reduced wound contraction, improved wound healing and better vascularization and re-epithelialization after transplantation of collagen-glycosaminoglycan substitutes seeded with autologous bone marrow-derived MSCs in partial thickness burn wounds using a porcine model. Several tissues can serve as a source for MSCs, such as bone marrow, fat, gingiva, and dermis, as well as fetal tissue (umbilical cord, placenta) (Laverdet et al. 2014). However, the accessibility, cell number and availability can vary between the different tissues.

Fetal dermal cells which have MSC characteristics (Chinnici et al. 2014; Tan et al. 2014; Young et al. 2001) have been indicated as a promising cell source for cell-based therapy for skin regeneration. An essential advantage is that fetal skin cells have a better regenerative and higher proliferative capacity compared to adult cells (Ferguson et al. 1996; Kishi et al. 2012; Rolfe and Grobbelaar 2012; Yates et al. 2012). Fetal wounds are known to heal faster, and with nearly no scarring up to the middle of the third trimester (Ferguson et al. 1996; Satish and Kathju 2010). They also seem to have a higher recovery rate after cryopreservation compared to adult cells (Applegate et al. 2009; De Buys Roessingh et al. 2006). In addition, fetal cells have a low immunogenicity which is an advantage with respect to allograft transplantation and rejection. MHC molecules play an important role in this, since MSCs (Ryan et al. 2005), but also fetal dermal cells (Chinnici et al. 2014) $(<14$ weeks of gestation for humans) have a very limited expression of MHC class II molecules on their cell surface. The expression of MHC class II molecules remains absent after culturing of fetal dermal cells until passages 21-28 (Chinnici et al. 2014; Hohlfeld et al. 2005). Furthermore, MSCs have been shown to modulate $\mathrm{CD}^{+}$and $\mathrm{CD}^{+} \mathrm{T}$ lymphocyte responses in in vitro co-cultures (Barry et al. 2005; Ryan et al. 2005). In vitro studies showed, for example, that MSCs inhibited T lymphocyte proliferation, increased $\mathrm{CD} 4{ }^{+} \mathrm{CD} 25^{+} \mathrm{T}$ lymphocyte $\left(\mathrm{T}_{\text {regs }}\right)$ populations, suppressed $\mathrm{CD} 4^{+}$and $\mathrm{CD} 8^{+}$lymphocyte activity and created an immunosuppressive environment (Barry et al. 2005; Le Blanc 2003; Ryan et al. 2005).

All these advantages might allow the creation of a wellcharacterized fetal skin cell bank which could be used for cellbased therapies. Development of such an "off-the-shelf" product would remedy the cell number deficiency and decrease culture time for cell-based dermal substitutes. Applegate and colleagues have already investigated the establishment of a fetal skin cell bank (Applegate et al. 2009; De Buys Roessingh et al. 2006). They were able to create several million constructs out of just one $4 \mathrm{~cm}^{2}$ fetal dermal tissue biopsy (Applegate et al. 2009; Hohlfeld et al. 2005). Moreover, they used constructs with fetal skin cells for burn wounds in children and observed faster wound healing and less scarring (Hohlfeld et al. 2005). However, fetal constructs were topically administered and refreshed every dressing change. There are two explanations for the results of this study: migration of fetal dermal cells into the wound bed, or that these cells only provided growth factors, chemokines and cytokines by paracrine signaling (Chen et al. 2008; Gnecchi et al. 2008; Hocking and Gibran 2010). Furthermore, the burn wounds of the children treated with the fetal dermal constructs seemed relatively small, and were possibly not completely fullthickness wounds (Scott and Tredget 2005). Therefore, the beneficial effects of dermal substitutes containing fetal dermal cells for the application in full-thickness (burn) wounds remain to be elucidated.

The aim of our study was to investigate the effects of fetal dermal cells on wound healing and scarring of full-thickness wounds. A porcine full-thickness wound model was used to study the effect of a porcine collagen-based dermal substitute (Novomaix, NVM) seeded with human (xenogeneic) or porcine (allogeneic) fetal dermal cells in combination with a STSG on wound healing and scar formation. These treatments were compared to NVM seeded with autologous dermal 
fibroblasts. We investigated the wound healing and scar characteristics, as well as the inflammatory response of these different treatment modalities.

\section{Materials and methods}

\section{Fetal and autologous dermal fibroblast isolation}

\section{Human fetal fibroblasts}

Human fetal fibroblasts were isolated from fetal skin (derived from extremities) after pregnancy termination; the age of the fetus was 12 weeks (one donor). Fetal skin was obtained with the informed and written consent of the pregnant woman.

Skin tissue was washed with phosphate-buffered saline (PBS) and cut into small pieces for enzymatic treatment. Tissue was digested using $0.25 \%(\mathrm{w} / \mathrm{v})$ collagenase A and $0.25 \%$ (w/v) dispase II (Roche Diagnostics, France) in PBS for $1-2 \mathrm{~h}$ at $37{ }^{\circ} \mathrm{C}$ under agitation (van den Bogaerdt et al. 2002). Digested tissue was washed with PBS containing $1 \%$ fetal calf serum (FCS) (HyClone FetalClone III; Thermo Scientific, Etten-Leur, The Netherlands) and filtered over an open filter chamber (Beldico, Duiven, The Netherlands) to remove large tissue debris particles. Cells were pelleted by centrifugation for $10 \mathrm{~min}$ at $385 \mathrm{~g}$. Cell pellets were resuspended in fibroblast culture medium (FBM) which consisted of DMEM (Gibco, Paisley, UK) supplemented with $10 \% \mathrm{v} / \mathrm{v}$ FCS, $1 \mathrm{mM}$ L-glutamine, and the antibiotics penicillin (100 IU/mL) and streptomycin $(100 \mathrm{mg} / \mathrm{mL})$ (Gibco). The cell suspension was filtered through a 70- $\mu \mathrm{m}$ cell strainer (Falcon; Becton Dickinson, Mountain View, CA, USA) to remove any remaining tissue debris. Cells were pelleted (267g, $10 \mathrm{~min}$ ), resuspended in FBM and seeded with a cell density of $3 \times 10^{6}$ per $175-\mathrm{cm}^{2}$ tissue culture flask $\left(1.7 \times 10^{4}\right.$ per $\left.\mathrm{cm}^{2}\right)$. From human adult dermis, an average of $1 \times 10^{6}$ cells $/ g$ tissue can be obtained and for human (and porcine) fetal skin an average of $20 \times 10^{6}$ cells $/ g$ tissue. Cell doubling times for human adult fibroblasts is 4.6 days and for fetal fibroblasts 2.3 days. Cells were cultured until a sufficient amount of cells was obtained. Cells of passages P1-P4 were used in the experiment.

\section{Porcine fetal and autologous fibroblasts}

For the isolation of porcine fetal dermal cells, unborn piglets were isolated from a 60-day pregnant Yorkshire pig. Skin was taken from flanks of the piglets. For the isolation of autologous (adult) fibroblasts, two sheets $(5 \times 20 \mathrm{~cm}, 0.3 \mathrm{~mm})$ of split thickness autologous skin were taken from the back of the animals (from animals in which later full-thickness wounds were created) with an electrical dermatome. This was performed 1 week before transplantation. Isolation of the porcine autologous and fetal fibroblasts was performed as described above in 'human fetal fibroblasts'. Porcine fetal and autologous fibroblasts were cultured and seeded into Novomaix (NVM) dermal substitutes.

\section{Cell characterization}

hFF, $\mathrm{pFF}$ and AF were seeded onto glass slides with a density of 50,000 cells/slide. After 2-3 days of culture, cells were fixed with $4 \%$ formaldehyde for $15 \mathrm{~min}$ at RT. Cells of passages P2-P5 were used for immunohistochemistry. Cells were pretreated with $0.5 \%$ Triton X-100. Next, cells were stained for heat shock protein 47 (HSP47), which is used as a fibroblast marker, and $\alpha$ SMA for $1 \mathrm{~h}$ at RT (see Table 4 for antibodies and dilutions). Subsequently, slides were incubated for $45 \mathrm{~min}$ at RT in the dark using goat-anti-mouse Alexa488 (1:500, A21424; Life Technologies, VWR, Amsterdam, The Netherlands) and goat-anti-mouse Alexa555 (1:500, A11017; Life Technologies) respectively as secondary antibodies.

\section{Dermal substitute Novomaix}

Novomaix (NVM) (Matricel, Herzogenrath, Germany) collagen-elastin scaffolds (average pore size $100 \mu \mathrm{m}$ ) were used as dermal substitutes. The highly purified collagen and elastin fibers of this scaffold are of porcine origin. Characteristics and features of NVM have been described previously by Boekema et al. (2014). Three days before surgery, NVM was cut into pieces of $3.5 \times$ $3.5 \mathrm{~cm}$ and prewetted with FBM. Human (hFF) or porcine (pFF) fetal or autologous (AF) fibroblasts were seeded on top of the dermal substitutes with a cell density of $5 \times 10^{5}$ fibroblasts $/ \mathrm{cm}^{2}$. The cell suspension was absorbed by the dermal substitute. Two hours of incubation at $37{ }^{\circ} \mathrm{C}$ was implemented to allow fibroblasts to attach to NVM, and thereafter $20 \mathrm{~mL}$ of FBM culture medium containing $65 \mu \mathrm{g} / \mathrm{mL}$ vitamin C (Sigma Aldrich, Steinheim, Germany) was added per dermal substitute. Culture medium was replaced every day with medium with freshly added vitamin C until the day of surgery. The acellular NVM (AcellNVM) was treated similar to the cell-seeded NVM, only all procedural steps were without cells. Acellular and cellseeded substitutes were transplanted on excised fullthickness wounds on the day of surgery. Treatments were randomly appointed to the wounds per animal as described in Table 1. Two wounds per animal received the same treatment. The treatment with STSG alone is comparable to the treatment that is standard in the clinic. Furthermore, addition of AF to the dermal substitute NVM was also used as a control because these cells have already been shown to improve scar quality. 
Table 1 Treatment modalities of cell-seeded and control treatments

\begin{tabular}{lll}
\hline Treatment & Abbreviation treatment & Total number of wounds \\
\hline Split thickness skin graft & STSG & 12 \\
Novomaix (NVM) (acellular) + STSG & Acell-NVM & 12 \\
Human fetal dermal fibroblasts + NVM + STSG & NVM+hFF & 6 \\
Porcine fetal dermal fibroblasts + NVM + STSG & NVM+pFF & 6 \\
Autologous fibroblasts + NVM + STSG & NVM+AF & 12 \\
\hline
\end{tabular}

\section{Animal experiments, operative and bandaging procedures}

The institutional Animal Experiments Committee of the VU University Medical Center Amsterdam, The Netherlands, approved the experimental protocols according to governmental and international guidelines on animal experimentation. The pigs received a week's acclimatization period before the start of the experiment. The pigs were individually housed, fed twice a day and had access to water ad libitum. In total, six female Yorkshire pigs were used. Animals had an average body weight of $31 \mathrm{~kg}$ at the start of the experiment and an average of $67 \mathrm{~kg}$ at the end.

\section{Animal sedation/anesthesia/analgesia}

Twenty minutes before the start of the surgical procedure, the animals were sedated with a combination of Ketamine $10 \mathrm{mg} / \mathrm{kg}$, Dormicum (Midazolam) $0.5 \mathrm{mg} / \mathrm{kg}$ and Atropine $0.5-1.0 \mathrm{mg}$ by intramuscular (i.m.) injection. Anesthesia during the tattoo, biopsy, and bandage-change procedures was induced and maintained by $35 \% \mathrm{O}_{2}, 65 \%$ $\mathrm{NO}_{2}$ and 1.5-2.5\% Isoflurane via a mouth cap. Analgesic Novum 20 (Meloxicam, $0.04 \mathrm{mg} / \mathrm{kg}$ ) was administered i.m.

Before the surgery (creation of full-thickness wounds, application of dermal substitutes and STSG transplantations), full anesthesia was induced using Etomidate lipidor via intravenous (i.v.) injection (sedation), Dormicum (Midazolam) $15 \mathrm{mg}$, and as analgesia Fentanyl $200 \mu \mathrm{g}$ and muscle relaxant Pavulon (Pancuronium bromide) $6 \mathrm{mg}$ (i.v.). During surgery, the anesthesia was maintained by i.v. injection of Dormicum $0.5 \mathrm{mg} / \mathrm{kg} / \mathrm{h}$, Fentanyl $6.5 \mu \mathrm{g} / \mathrm{kg} / \mathrm{h}$ and Pavulon $0.27 \mathrm{mg} / \mathrm{kg} / \mathrm{h}$. Furthermore, artificial respiration with $45-50 \% \mathrm{O}_{2}$ and $1.5-2.5 \%$ Isoflurane was provided when the animals received full anesthesia. Vital functions such as $\mathrm{CO}_{2}$ expiration concentration, blood gas values, heart rate and temperature were monitored during surgery. Direct post-operative analgesia was administered by i.m. injection of Buprenorphine $0.3 \mathrm{mg}$. After the surgical procedure, $5 \mu \mathrm{g} / \mathrm{kg}$ Buprenorphine was administered at least once, or every 10-12 $\mathrm{h}$ when there was indication of pain. Metacam was orally administered once a day for a period of 2 weeks.

\section{Surgical procedure}

Surgical procedures of these animal experiments were performed using the porcine excisional wound model described by Middelkoop et al. (2004). In short, 1 week before the creation of the full-thickness wounds, a grid of $7 \times 7 \mathrm{~cm}$ squares was tattooed on both flanks of the pigs. This grid is used to correct for the growth of the animal. At the day of surgery, seven full-thickness, 2 .7-mm-deep wounds of $3 \times 3 \mathrm{~cm}$ squares were created on each flank of the pig. Autologous STSGs (0.3 mm thickness) were obtained from the wound sites using an electrical dermatome (Humeca, Enschede, The Netherlands). STSG were meshed (Humeca) in a 1:3 ratio and kept moisturized in sterile PBS-soaked gauzes until use. Wounds were excised with a scalpel to full-thickness (until the subcutaneous fat layer). Twelve of 14 full-thickness wounds per animal were transplanted with a dermal substitute (NVM), with or without cells, and covered with a meshed STSG. Two of the 14 wounds per animal received only an STSG. Dermal substitutes and STSGs were fixed with staples (3M, Delft, The Netherlands). The different treatments were randomized over the seven wounds on each flank. Two wounds per animal received the same treatment. Three of the seven wounds per flank received other treatments, which will not be described in this article. Therefore, the number of wounds described in this article is in total 48. Wounds were dressed with adhesive Alleveyn (gentle border $10 \times 10 \mathrm{~cm}$; Smith \& Nephew, Hull, UK) to protect against mechanical trauma and contamination. Sterile gauzes $(45 \times 70 \mathrm{~cm})$ were used to cover the Alleveyn bandages, and were fixed with adhesive bandage Curafix (Lohmann \& Rauscher, Neuwied, Germany) and the elastic stocking Tubigrip was used (Klinion; Mediq Medeco, OudBeijerland, The Netherlands).

\section{Macroscopic wound evaluation and dressing changes}

Wounds were macroscopically evaluated during dressing changes at 4, 7, 14, 21 days, and at the end of the experiment at 56 days post-surgery. Macroscopic evaluation of the wounds was performed by 2-3 independent trained observers who were blinded for the treatment. Parameters used in the macroscopic evaluation were obtained and adjusted from the observer part of the Patient and Observer Scar Assessment Scale (POSAS). The POSAS is a validated method used for 
scar evaluation in patients in the clinic (Draaijers et al. 2004; van der Wal et al. 2012). Wounds were evaluated for graft take, wound color, wound closure, wound thickness, skin smoothness and wound pliability (Table 2). At the end of the experiment (day 56), each wound was given an overall observer score for scar quality (Table 2). This scar quality score was based on all scored parameters (such as contraction, redness, thickness and relief) at day 56 .

Digital pictures of the wounds were taken on days 0 , $4,7,14,21$ and 56. To measure contraction of the wound at days 0,21 and 56, the wound edges and tattoo grid were traced onto a transparent sheet. Contraction was determined by planimetry (NIS Elements, v.3.1; Nikon, Badhoevedorp, The Netherlands) and corrected for the growth of the animal by calculating the wound area as a ratio of the area of the tattoo grid. This was subtracted from the original wound/tattoo grid area relation of day 0 . Contraction is expressed as percentage contraction of the wound compared to day 0 which was set at $0 \%$ (no contraction). The measurement of wound contraction is explained in Lammers et al. (2011: fig. 2). Two punch biopsies (Ø $4 \mathrm{~mm}$ ) of the wounds were taken on days $4,7,14$ and 21 , in a systematic order. At the end of the experiment (day 56), the animals were euthanized with $30 \mathrm{~mL}$ pentobarbital sodium i.v., and subsequently a large biopsy across the center of the wound was taken. Wound biopsies were fixed in Kryofix (48 \% ethanol, $7 \%$ polyethylene glycol (PEG)-300) and stored at $4{ }^{\circ} \mathrm{C}$, or snap-frozen in liquid nitrogen and stored at $-80{ }^{\circ} \mathrm{C}$ until further analysis.

\section{Microscopic wound evaluation}

Kryofixed tissue biopsies were dehydrated, embedded in paraffin and cut into sections of $5-\mu \mathrm{m}$ thickness. For (immuno)histochemical stainings, sections were deparaffinized and rehydrated. A hematoxylin (Mayers; DAKO, Glostrup, Denmark) and eosin (Sigma-Aldrich) staining was performed to evaluate dermal substitute presence, epidermis, number of foreign body giant cells (FBGC) and granulation tissue thickness (Table 3). Granulation thickness was measured using digital image analysis (NIS Elements, v.3.1).

Presence of myofibroblasts in wound tissue sections was assessed by $\alpha$ SMA expression using an antibody against $\alpha$ SMA (Table 4). Sections were stained with an antibody directed against CD31 to study the presence of blood vessels (Table 4). Neutrophils were stained using an antibody directed against MPO (Table 4). To investigate the treatment effects on the immunological response, frozen sections $(5 \mu \mathrm{m})$ were stained for immune cells: macrophages (CD163), $\mathrm{CD}^{+}$and $\mathrm{CD} 8^{+}$ lymphocytes (Table 4).

Slides were incubated with secondary antibodies BrightVision Poly-HRP anti-mouse or anti-rabbit (Immunologic, Duiven, The Netherlands). The substrate 3,3'-Diaminobenzidine (DAB) (Immunologic) was used to visualize the staining. Tissue sections were counterstained with hematoxylin. We determined the wound area positive for $\alpha$ SMA expression by selection of the DAB signal in the tissue using NIS Elements (Nikon). The area of the DAB signal was expressed as a fraction of the total wound area. Immune cells were scored for presence on a scale of 0 (not present) to 5 (severe influx). All microscopic analyses were performed blinded to the treatment and scored by at least two trained observers.

\section{Statistics}

All statistical analyses were performed with SPSS (v.21.0 MS Windows; SPSS, Chicago, IL, USA). Statistically significant differences between treatment groups were determined by using the nonparametric KruskalWallis test. A two-tailed Mann-Whitney $U$ test was used as a post hoc test. A $p$ value of $<0.05$ was considered statistically significant. Graph bars represent the mean and the standard deviation per treatment.

Table 2 Parameters for macroscopic wound evaluation

\begin{tabular}{|c|c|c|}
\hline Parameter & Score & Description \\
\hline Graft take & Percentage (\%) of vital graft from total graft & $\begin{array}{l}\text { I.e., viability of the graft (pink color) and adherence } \\
\text { to the wound bed }(\%)\end{array}$ \\
\hline Wound closure & $\begin{array}{l}\text { Percentage }(\%) \text { of total wound area that is } \\
\text { covered by epithelium }\end{array}$ & Re-epithelialization of the wound area \\
\hline Wound color & Scale 0 to 5 & Compared to unaffected skin (pink, $=0$ ),$+5=$ purple $/$ red \\
\hline Wound thickness (depth) & Scale -5 to 5 & $\begin{array}{l}\text { Level compared to normal epidermis level }(=0) \text {, } \\
\qquad-5=\text { deep wound, }+5=\text { raised wound }\end{array}$ \\
\hline $\begin{array}{l}\text { Distortion } \\
\text { (compared to original wound shape) }\end{array}$ & Scale 0 to 5 & $\begin{array}{l}0=\text { original size wound square, } 5=\text { severe star-shaped } \\
\text { wound area }\end{array}$ \\
\hline Observer score (scar quality) & Scale 1 to 10 & Compared to unaffected skin ( $1=$ unaffected skin $)$ \\
\hline
\end{tabular}


Table 3 Parameters for microscopic wound evaluation

\begin{tabular}{|c|c|c|}
\hline Parameters & Score & \\
\hline Presence of dermal substitute & Scale 0 to 3 & $\begin{array}{l}0=\text { no dermal substitute remnants, } \\
3=\text { intact dermal substitute structure }\end{array}$ \\
\hline Epidermis & Scale 0 to 3 & $\begin{array}{l}0=\text { no epidermis, } 3=\text { hyperproliferation } \\
\text { of keratinocytes }\end{array}$ \\
\hline $\begin{array}{l}\text { Foreign body giant cells } \\
\text { (FBGC) }\end{array}$ & $\begin{array}{l}\text { Number of FBGC cells in } \\
\text { wound area of the tissue section }\end{array}$ & \\
\hline Thickness granulation tissue & Micrometer $(\mu \mathrm{m})$ & $\begin{array}{l}\text { Distance from start of dermis to } \\
\text { subcutaneous fat layer }\end{array}$ \\
\hline
\end{tabular}

\section{Results}

\section{Mesenchymal stem cell characteristics of fetal dermal cells}

The presence of mesenchymal stem cells in a fetal dermal cell population and their characteristics were assessed by flow cytometric analysis and differentiation capacity. Human fetal dermal cells were positive for CD105, CD73 and CD90, and were negative for CD14, CD31, CD34, CD45, CD79a and HLA-DR (data not shown). Both human and porcine fetal dermal cells were able to differentiate into osteoblasts, chondrocytes and adipocytes (data not shown). These results meet the criteria as defined by Dominici et al. (2006). Phenotypical characterization of adult MSCs derived from different sources has been described by van den Bogaerdt et al. (2009). $\mathrm{AF}, \mathrm{hFF}$ and $\mathrm{pFF}$ cultured on glass slides showed similar staining of the cytoplasm for HSP47 (Fig. 1d-f). $\alpha$ SMA expression in these cells was also similar for AF and pFF; however, the $\alpha \mathrm{SMA}$ expression in hFF seemed slightly lower (Fig. 1a-c). $\alpha$ SMA expression by these cells was represented as a stress fiber phenotype.

\section{Autologous fibroblasts in collagen-based dermal substitutes improved scar quality}

Scars of the differently treated wounds were macroscopically evaluated 56 days post-surgery using an adapted POSAS scar assessment scale (Table 2). A lower score represents a better scar quality, indicating closer similarity to unaffected skin. Figure 2 a illustrates a macroscopic view of the scars at 56 days post-surgery. Wounds transplanted with NVM+hFF, NVM+ pFF, Acell-NVM or STSG demonstrated a more star-shaped scar (distortion) compared to wounds treated with NVM+AF. The overall observer scores (scar quality) of the NVM+hFF and NVM+pFF group were similar to STSG and Acell-NVM treatment (Fig. 2b). Wounds treated with NVM+AF showed an improved scar quality compared to Acell-NVM, NVM+ hFF and $\mathrm{NVM}+$ pFF at post-surgery day 56 (Fig. 2b). No differences of other macroscopic (Table 2) and microscopic (Table 3) evaluation scores were observed between the different treatments.

\section{Collagen-based dermal substitutes seeded with autologous fibroblasts reduced scar contraction and $\alpha$ SMA expression}

Excessive wound contraction is a frequently encountered characteristic of burn wound scars. Contraction of the wound was macroscopically evaluated (see description above), but also determined by planimetric analysis at days 21 and 56 post-surgery (Fig. 3a). Increased contraction was noted for wounds treated with $\mathrm{NVM}+\mathrm{hFF}$ versus Acell-NVM at day 21. Full-thickness wounds transplanted with $\mathrm{NVM}+\mathrm{hFF}$ or $\mathrm{NVM}+\mathrm{pFF}$ showed statistically significantly more contraction compared to $\mathrm{NVM}+\mathrm{AF}$ at post-wounding days 21 and 56 (Fig. 3b). A lower wound contraction was only observed in wounds transplanted with NVM+hFF compared to $\mathrm{NVM}+\mathrm{pFF}$ at day 21. Furthermore, addition of AFs to a dermal substitute reduced contraction of full-thickness

Table 4 Primary antibodies

\begin{tabular}{llll}
\hline Primary antibody & Clone & Dilution & producer \\
\hline Anti - $\alpha$ SMA & 1A4 & $1: 500$ & DAKO, Glostrup, Denmark \\
Anti - CD31 & SP38 (M3380) & $1: 150$ & Abbiotec, San Diego, CA, USA \\
Anti - MPO & A0398 & $1: 1200$ & DAKO, Glostrup, Denmark \\
Anti - CD163 & MAC2.48 & $1: 1000$ & IQproducts, Groningen, The Netherlands \\
Anti - CD4 & MIL17 (MCA1749) & $1: 50$ & AbD Serotec, Puchheim, Germany \\
Anti - CD8 & MIL12 (MCA1223) & $1: 100$ & AbD Serotec, Puchheim, Germany \\
Anti - HSP47 & M16.01A1 & $1: 500$ & Enzo Life Sciences, Raamsdonksveer, The Netherlands \\
\hline
\end{tabular}


Fig. 1 Cell characterization by $\alpha$ SMA and HSP47 expression in $\mathrm{hFF}, \mathrm{pFF}$ and $\mathrm{AF}$ (porcine), cells cultured on glass for 2-3 days and stained for DAPI (blue), HSP47 (green) and $\alpha$ SMA (red). a-c All cell sources showed a number of $\alpha$ SMA positive cells in the cell population. All $\alpha$ SMA positive cells showed stress fiber formation. d-f $\mathrm{HSP} 47$ stained the cytoplasm of all cells, indicating their fibroblastic phenotype. Scale bars $50 \mu \mathrm{m}$
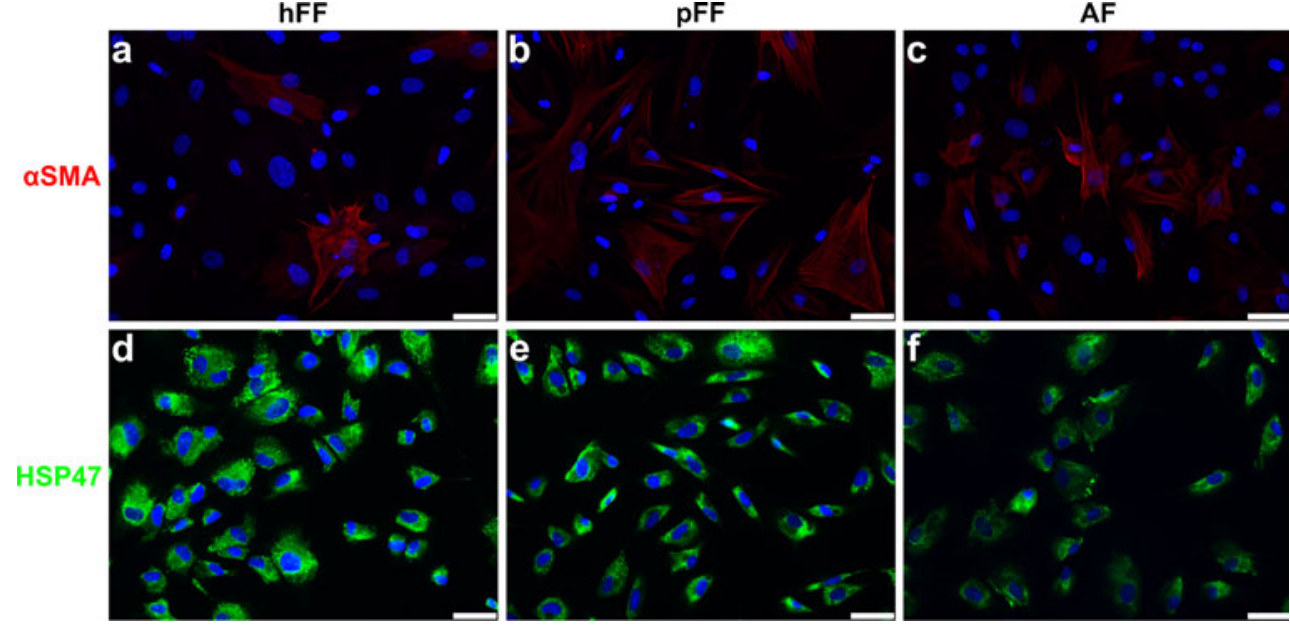

wounds in comparison Acell-NVM (day 21 and 56). Overall, contraction increased over time.

The presence of myofibroblasts in the wound area was analyzed by immunohistochemical staining of $\alpha \mathrm{SMA}$ at day 14 . Figure $3 b$ illustrates that a statistically significantly larger fraction of the total wound area was $\alpha$ SMA positive in wounds transplanted with $\mathrm{NVM}+\mathrm{hFF}$ or $\mathrm{pFF}$ compared to $\mathrm{NVM}+\mathrm{AF}$. Wounds of NVM+hFF showed a clear $\alpha \mathrm{SMA}-$ positive expression in the granulation tissue (Fig. 3c), while $\alpha$ SMA-positive expression was significantly less in wounds of NVM+AF (Fig. $3 \mathrm{~d}$ ) at day 14. Induction of $\alpha \mathrm{SMA}$ expression in the wound area tended to be less in wounds treated with $\mathrm{NVM}+\mathrm{pFF}$ compared to $\mathrm{NVM}+\mathrm{hFF}(p=0.055)$. It is noteworthy that the addition of AF to NVM significantly reduced the $\alpha$ SMA expression in the wound area compared to Acell-NVM at day 14.

\section{Increased influx of inflammatory cells after transplantation of fetal fibroblasts}

NVM seeded with hFFs or pFFs did not improve the macroscopic scar characteristics or scar quality compared to the Acell-NVM treatment. Since inflammation can influence scar formation, the presence of inflammatory cells such as neutrophils, macrophages, $\mathrm{CD} 4^{+}$and $\mathrm{CD} 8^{+} \mathrm{T}$ lymphocytes in the wound area was investigated.

Neutrophils and macrophages play an important role in clearing of infections and tissue debris (e.g., dead cells). An increased

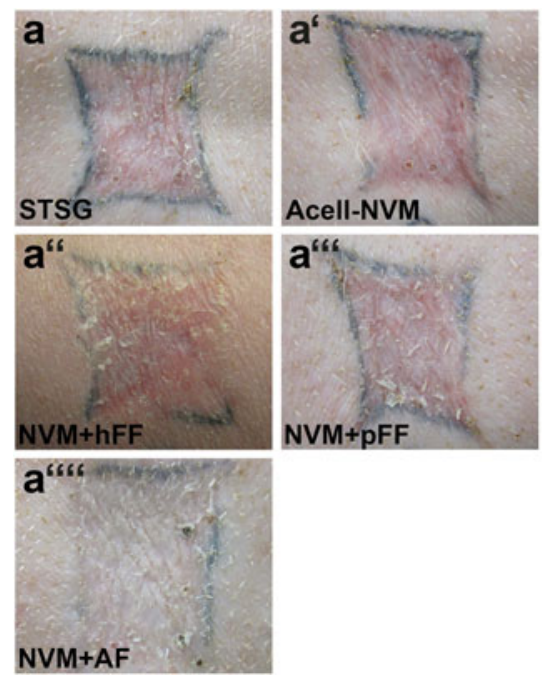

Fig. 2 Macroscopic evaluation of treated wounds at day 56. a Representative photographs of wounds per treatment. b Scar quality (overall observer score) as determined by scoring parameters of the POSAS scale. Scar quality was improved (represented by lower scores) in wounds transplanted with $\mathrm{NVM}+\mathrm{AF}$ ( $n=12$ wounds) compared to Acell-NVM ( $\S, n=12$ wounds), NVM+hFF (*, n=6 wounds) and

b

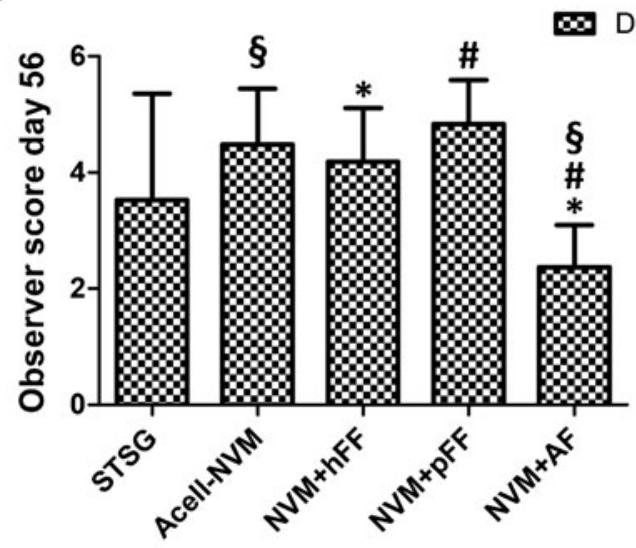

$\mathrm{NVM}+\mathrm{pFF}$ (\#, $n=6$ wounds). Statistical significance is indicated by symbols (Mann-Whitney $U$ test, $p<0.05$ ). STSG Split thickness skin graft, Acell-NVM Novomaix+STSG, $N V M+h F F$ Novomaix containing human fetal fibroblasts + STSG, $N V M+p F F$ Novomaix containing porcine fetal fibroblasts + STSG, $N V M+A F$ Novomaix containing autologous fibroblasts + STSG 
a

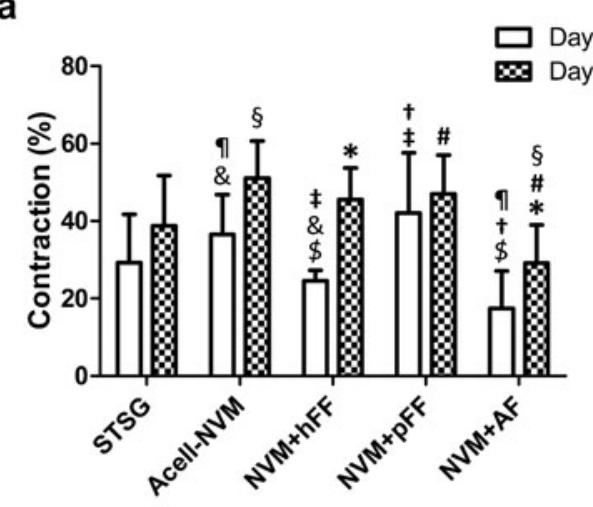

b

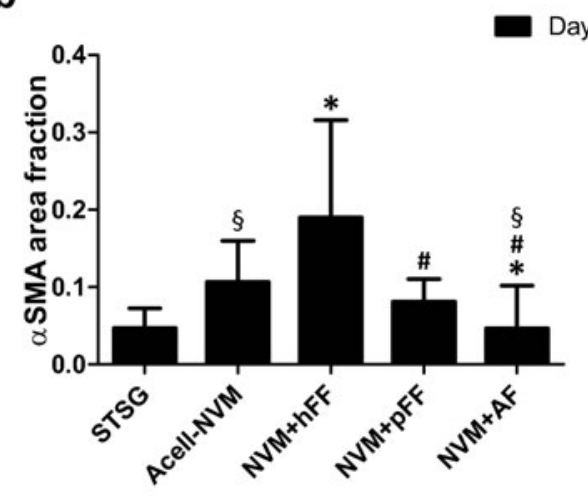

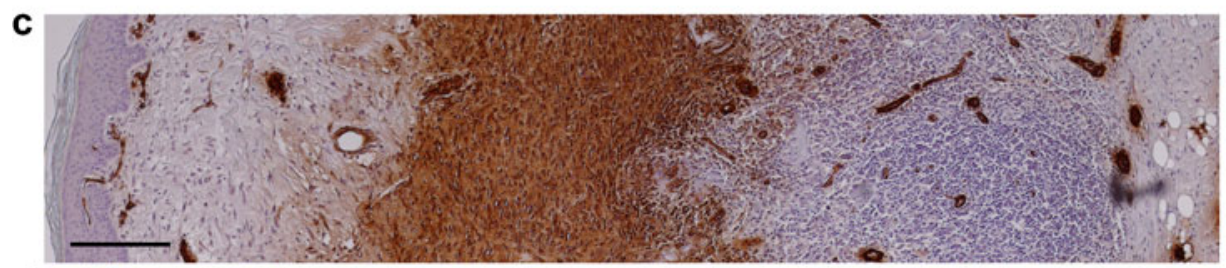

d

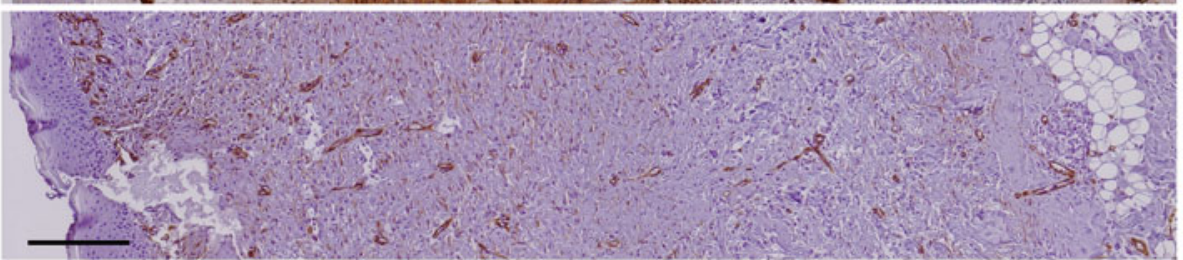

Fig. 3 Wound contraction and $\alpha \mathrm{SMA}^{+}$myofibroblasts in the wound area. a Planimetric analysis of wound area to determine wound contraction at day 21 and day 56. Contraction is expressed as percentage contraction of total wound area. NVM+AF $(n=12)$ showed a reduction in the contraction of the wound compared to Acell-NVM ( $\Phi$, $\S, n=12), \mathrm{NVM}+\mathrm{hFF}(\$, *, n=6)$ and $\mathrm{NVM}+\mathrm{pFF}(\dagger, \#, n=6)$. Statistical significance is indicated by symbols (Mann-Whitney $U$ test, $p<0.05$ ). b An immunohistochemical staining for $\alpha$ SMA was performed to detect the presence of myofibroblasts in the wound at post-surgery day 14. $\alpha \mathrm{SMA}$ expression of myofibroblasts was calculated as fraction of the wound area. Wounds transplanted with $\mathrm{hFF}$ showed an increased expression of $\alpha \mathrm{SMA}$ in the wound area compared to $\mathrm{NVM}+\mathrm{AF}(*)$ at day 14 . NVM+ AF showed a reduced $\alpha \mathrm{SMA}$ expression in the wound in comparison with Acell-NVM (§), NVM+hFF (*) and NVM+pFF (\#). c, d Representative pictures of wound tissue sections stained for $\alpha \mathrm{SMA}$ (DAB, in brown) at day 14. Full-thickness wound transplanted with $\mathrm{NVM}+\mathrm{hFF}$ (c) showed higher $\alpha \mathrm{SMA}$ expression in the wound area compared to $\mathrm{NVM}+\mathrm{AF}(\mathbf{d})$

One of the most important issues with allogeneic and xenogeneic transplantation is the rejection of graft cells by the receiver. Both $\mathrm{CD}^{+}$and $\mathrm{CD} 8^{+}$lymphocytes play a role in this process. Especially, cytotoxic $\mathrm{CD} 8^{+}$lymphocytes are able to recognize foreign MHC molecules. Full-thickness wounds transplanted with $\mathrm{NVM}+\mathrm{hFF}$ induced the influx of $\mathrm{CD} 4^{+}$ and $\mathrm{CD} 8^{+}$lymphocytes in comparison to Acell-NVM and $\mathrm{NVM}+\mathrm{AF}$ at days 7 and 14 post-surgery (Fig. 5). Enhanced influx of $\mathrm{CD}^{+}$lymphocytes was observed for $\mathrm{NVM}+\mathrm{hFF}$ compared to NVM+pFF at day 14 (Fig. 5a, b). Remarkably, $\mathrm{CD}^{+}$lymphocyte scores were reduced for all treatment groups at day 14 , except for the $\mathrm{hFF}$ group. The $\mathrm{CD}^{+}$lymphocyte score for $\mathrm{NVM}+\mathrm{hFF}$ treatment remained at the same level as day 7 . This suggests that the $\mathrm{CD}^{+}$lymphocyte response is prolonged when wounds are transplanted with NVM containing hFF. Besides an induction in the influx of $\mathrm{CD} 4{ }^{+}$ lymphocytes within the NVM+hFF group, an elevation in the $\mathrm{CD} 8^{+}$lymphocyte influx was also noticed. Both NVM+hFF and $\mathrm{NVM}+\mathrm{pFF}$ groups induced the $\mathrm{CD} 8^{+}$lymphocyte influx 
a

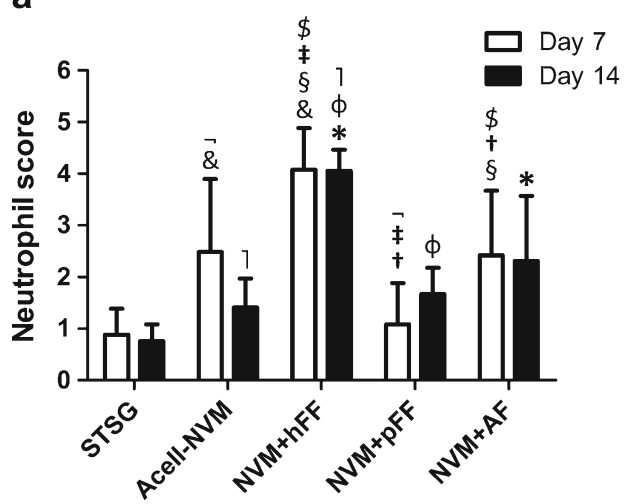

Fig. 4 Neutrophil and macrophage influx in full-thickness wounds. Immune cells were detected with immunohistochemistry and scored blinded upon grades of influx from 0 (none) to 5 (massive influx). a Neutrophils were stained with an antibody directed against myeloperoxidase (MPO). Increased neutrophil scores were observed in wounds transplanted with NVM+hFF compared to Acell-NVM (\&, 1),

compared to Acell-NVM at days 7 and 14 (Fig. 5). Fourteen days post-surgery, the scores of $\mathrm{CD} 8^{+}$lymphocytes of NVM+ $\mathrm{hFF}$ and $\mathrm{NVM}+\mathrm{pFF}$ remained at a similar level as at day 7 . At day 14, no differences in $\mathrm{CD}^{+}$lymphocyte scores were observed in wounds treated with $\mathrm{NVM}+\mathrm{AF}$ in comparison with Acell-NVM. Interestingly, NVM+hFF (days 7 and 14) and $\mathrm{NVM}+\mathrm{pFF}$ (day 14) transplanted wounds showed a higher $\mathrm{CD} 8{ }^{+}$lymphocyte increase than $\mathrm{NVM}+\mathrm{AF}$ transplanted wounds.

\section{Discussion}

Fetal dermal cells have been proposed as a potential alternative cell source replacing autologous cells in cell-based

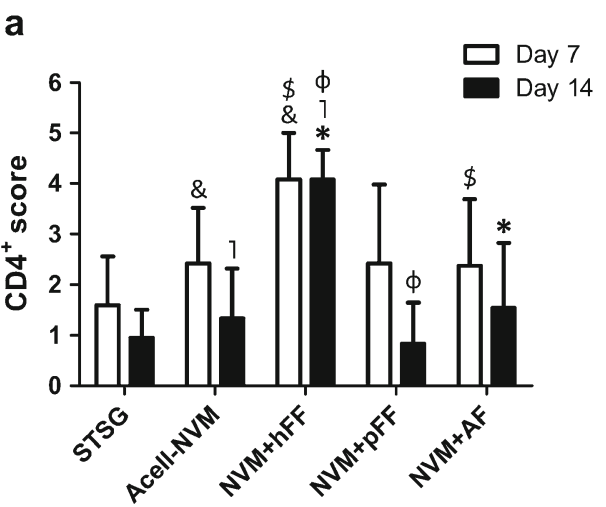

Fig. 5 Influx of $\mathrm{CD} 4^{+}$and $\mathrm{CD} 8^{+}$lymphocytes in full-thickness wounds. The influx of $\mathrm{CD}^{+}$and $\mathrm{CD} 8^{+}$lymphocytes in the wounds was scored blinded for each treatment group (on a scale of 0 (none) to 5 (massive influx)). a Score of $\mathrm{CD}^{+}$lymphocyte influx in the wound area. A statistically significant higher influx of $\mathrm{CD}^{+}$lymphocyte was observed in wounds transplanted with NVM+hFF compared to Acell-NVM $(\&, 1)$, b

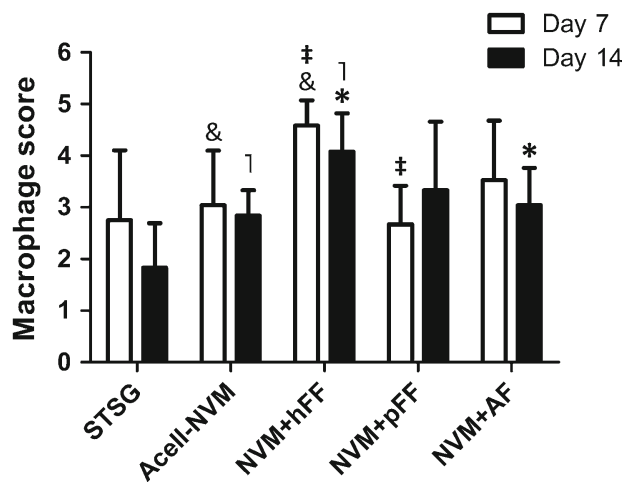

$\mathrm{NVM}+\mathrm{pFF}(\dagger, \varnothing)$ and NVM+AF $(\$, *)$ (days 7 and 14). b Influx of macrophages (antibody MAC 2.48) in wounds was scored per treatment for post-surgery day 7 and 14 . NVM+hFF induced the macrophage influx in the wound area compared to Acell-NVM (\&, 1, days 7 and 14) and NVM+AF (*, day 14). Statistical significance indicated by symbols (Mann-Whitney $U$ test, $p<0.05$ )

transplantation therapies. This is largely based on their multipotency, hypothesized hypo-immunogenicity and high expansion rate. It is important to gain knowledge about these fetal dermal cells and their behavior in a wound environment, before they can be used as cell-based therapy in the clinic.

Most importantly, this study showed that transplantation of excised full thickness wounds with either NVM+hFF or $\mathrm{NVM}+\mathrm{pFF}$ did not improve nor deteriorate scar quality in comparison to an acellular NVM substitute in the porcine model after 56 days. Wounds that were transplanted with NVM containing autologous fibroblasts (AF) demonstrated a better scar quality 56 days post-surgery than wounds treated with NVM without cells or with fetal cells. Full-thickness wounds treated with $\mathrm{NVM}+\mathrm{AF}$ also resulted in a reduced wound contraction and $\alpha \mathrm{SMA}$ expression in the wound area

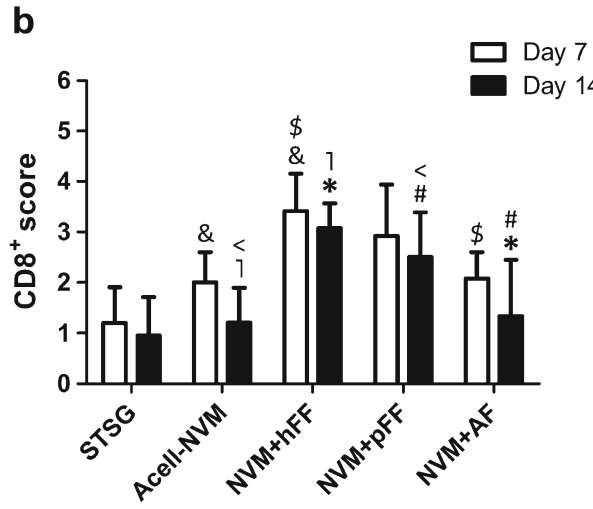

and NVM+AF $(\$, *)$ (days 7 and 14). b Influx scores of CD8 $8^{+}$ lymphocytes infiltrated into the wound area. Higher influx of $\mathrm{CD} 8^{+}$ lymphocytes was observed in wounds treated with $\mathrm{NVM}+\mathrm{hFF}$ or $\mathrm{NVM}+\mathrm{pFF}$ in comparison to Acell-NVM (vs. hFF: \&, 1; vs. pFF: <) and $\mathrm{NVM}+\mathrm{AF}$ (vs. hFF:\$, *; vs. pFF: \#). Statistical significance is indicated with symbols (Mann-Whitney $U$ test, $p<0.05$ ) 
compared to $\mathrm{NVM}+\mathrm{hFF}, \mathrm{NVM}+\mathrm{pFF}$ and Acell-NVM treatment groups. These findings indicate that fetal dermal cells behave differently from autologous dermal fibroblasts in excised full-thickness wounds. Several factors can account for the different behavior of these multipotent fetal dermal cells. Possible factors that play a role at an inflammatory level will be discussed first. Second, we will discuss the influence of fetal dermal cells on $\alpha \mathrm{SMA}$ expression, and finally the limitations of this study.

The increased inflammatory response in wounds transplanted with either hFFs or pFFs is in contrast to the described hypo-immunogenic characteristics of (human) fetal MSCs (Chen et al. 2011; Le Blanc 2003). However, not all published results seem to support the hypo-immunogenic characteristics of allogeneic MSCs used in transplantations, as discussed by Griffin et al. (2013) and reported by Nauta et al. (2006). A possible explanation for the enhanced immune response towards xeno-or allo-transplanted fetal dermal cells in this study could be the induction of a host versus graft immune response. This is mainly coordinated by $\mathrm{T}$ lymphocytes, and in this study $\mathrm{CD}^{+}$and $\mathrm{CD} 8^{+}$lymphocytes tended to be increased in the treatment with $\mathrm{NVM}+\mathrm{hFF}$, and $\mathrm{CD} 8^{+}$lymphocytes also in the NVM+pFF group. This immune response could be triggered by antigens derived from the transplanted xenogeneic $\mathrm{hFF}$ or allogeneic $\mathrm{pFF}$ or MHC expression on these cells induced by the wound environment (Glenn and Whartenby 2014; Singer and Caplan 2011). It has been suggested by Ren et al. $(2008,2009)$ that immunosuppressive effects of MSCs are strongly dependent on their microenvironment. Glenn et al. (2014) observed that co-culture of active CD8 ${ }^{+}$ lymphocytes with MSCs significantly induced the expression of MHC class I molecules on MSCs, and MSC cell death. Furthermore, the presence and concentration of inflammatory cytokines has been hypothesized to influence the polarization of MSCs towards a pro-inflammatory (MSC1) or antiinflammatory phenotype (MSC2) (Glenn and Whartenby 2014; Singer and Caplan 2011; Wang et al. 2014). The differentiation of the fetal dermal cells towards an MSC1 type might also explain the enhanced inflammatory response. However, this needs to be further investigated.

In addition to enhanced inflammation in the case of fetal dermal cells, we observed a significant increase in $\alpha$ SMA expression in the wound area of the NVM+hFF group compared to NVM+AF at day 14 . Similarly, wounds treated with pFFs showed a slightly elevated $\alpha$ SMA expression in the wound area in comparison with $\mathrm{NVM}+\mathrm{AF}$, but this seemed to be lower than NVM+hFF. This suggests that the enhanced or prolonged inflammatory response of fetal fibroblasts induces $\alpha$ SMA expression. Another possibility is that dermal fetal cells influence $\alpha$ SMA expression and transition to myofibroblasts by the secretion of growth factors and cytokines. MSCs express TGF- $\beta 1$ (Barry et al. 2005; Glenn and Whartenby 2014; Yoon et al. 2010) and can also differentiate into myofibroblasts in response to TGF- $\beta 1$ (Glenn and Whartenby 2014; Kim et al. 2014; Mishra and Banerjee 2011; Popova et al. 2010). Increased myofibroblast numbers and $\alpha$ SMA expression are hallmarks for fibrosis and scar formation.

Another reason for the lack of beneficial effects of fetal dermal cells can be that the survival time of the transplanted fetal dermal cells is limited. It has been reported that cultureexpanded MSCs (mostly with bone marrow-derived MSCs) have a short survival time after transplantation (Eggenhofer et al. 2014; Nuschke 2014) and show little engraftment (Eggenhofer et al. 2014). A limited survival time of MSCs is possibly induced by the culture procedure (Eggenhofer et al. 2014) or by a pro-inflammatory wound bed environment (Nuschke 2014). Effects of the fetal dermis-derived MSCs can also be dependent on the timing of administration (Nuschke 2014; Ren et al. 2008; Shi et al. 2010; Wang et al. 2014). In this study, fetal dermal cells were directly transplanted after excision of the wound. Timing of administration is correlated with the wound bed milieu during wound healing. It has been hypothesized that the immunosuppressive action of MSCs is induced under highly pro-inflammatory conditions (Glenn and Whartenby 2014). This suggests that administration of MSCs at the peak of inflammation during the wound healing can be more effective.

In this study we were unable to establish beneficial effects of fetal dermal cells in NVM substitutes on wound healing and scar formation in a full-thickness porcine wound model in comparison to STSG, Acell-NVM and NVM+AF. Case reports and a clinical study have reported beneficial effects in burn wound healing by injection of bone marrow-derived MSCs (Bey et al. 2010; Lataillade et al. 2007; Rasulov et al. 2005; Rigotti et al. 2007; Sheng et al. 2009). Furthermore, improved scar quality was observed for hypertrophic burn scars injected with adipose-derived MSCs (Klinger et al. 2008). In contrast to our study, in those studies MSCs were directly injected in the area of interest and derived from a different source, mostly autologous adult MSCs. Differences in MSC origin and populations have been reviewed by Hass et al. (2011). In several animal studies, accelerated wound healing and reduced scar formation were observed when cutaneous wounds were transplanted with human MSCs (Stoff et al. 2009; Xue et al. 2013). However, these studies were mostly performed in rodent models in which wound healing is mainly mediated through contraction. The outcomes from these rodent models are therefore less predictive for the human wound healing process.

\section{Conclusion}

Based on the results obtained in this study, we prefer the use of $\mathrm{AF}$ over that of $\mathrm{pFF}$ and $\mathrm{hFF}$ in full-thickness wounds to 
restore the dermal tissue function. In the literature, it is described that autologous as well as allogeneic MSCs seem to have great potential in the use of tissue regeneration. However, we were unable to prove an additional regenerative capacity of multipotent fetal dermal cells seeded in Novomaix and transplanted in excised full-thickness wounds. Differences between fetal dermis-derived MSCs and adult dermis-derived MSCs, and also between autologous versus allogeneic cells, should be further investigated before these can be used as a potential cell source for cell-based therapies. Especially, the influence of inflamed environments on the polarization of dermis-derived fetal MSCs towards a pro-inflammatory or anti-inflammatory phenotype needs to be further elucidated.

Acknowledgments We would like to thank Matricel GmbH, Herzogenrath, Germany for the kind gift of the collagen-elastin dermal substitute Novomaix. We would like to acknowledge K.W. Meyer and P. Sinnige for their assistance during the animal experiments and animal care. This project was financially supported by The Dutch Burn Foundation, Beverwijk, The Netherlands (project NBS WO 10.109) and the European Commission (FP7-HEALTH-2011-1, Grant Agreement no. 279024), project EuroSkinGraft.

Open Access This article is distributed under the terms of the Creative Commons Attribution 4.0 International License (http:// creativecommons.org/licenses/by/4.0/), which permits unrestricted use, distribution, and reproduction in any medium, provided you give appropriate credit to the original author(s) and the source, provide a link to the Creative Commons license, and indicate if changes were made.

\section{References}

Applegate LA, Scaletta C, Hirt-Burri N, Raffoul W, Pioletti D (2009) Whole-cell bioprocessing of human fetal cells for tissue engineering of skin. Skin Pharmacol Physiol 22:63-73

Barry FP, Murphy JM, English K, Mahon BP (2005) Immunogenicity of adult mesenchymal stem cells: lessons from the fetal allograft. Stem Cells Dev 14:252-265

Bey E, Prat M, Duhamel P, Benderitter M, Brachet M, Trompier F, Battaglini P, Ernou I, Boutin L, Gourven M, Tissedre F, Crea S, Mansour CA, de Revel T, Carsin H, Gourmelon P, Lataillade JJ (2010) Emerging therapy for improving wound repair of severe radiation burns using local bone marrow-derived stem cell administrations. Wound Repair Regen 18:50-58

Bloemen MC, van Leeuwen MC, van Vucht NE, van Zuijlen PP, Middelkoop E (2010) Dermal substitution in acute burns and reconstructive surgery: a 12-year follow-up. Plast Reconstr Surg 125: $1450-1459$

Boekema BHL, Vlig M, Olde Damink L, Middelkoop E, Eummelen L, Bühren A, Ulrich MW (2014) Effect of pore size and cross-linking of a novel collagen-elastin dermal substitute on wound healing. J Mater Sci Mater Med 25:423-433

Chen L, Tredget EE, Wu PY, Wu Y (2008) Paracrine factors of mesenchymal stem cells recruit macrophages and endothelial lineage cells and enhance wound healing. PLoS ONE 3:e1886

Chen PM, Yen ML, Liu KJ, Sytwu HK, Yen BL (2011) Immunomodulatory properties of human adult and fetal multipotent mesenchymal stem cells. J Biomed Sci 18:49

Chinnici CM, Amico G, Monti M, Motta S, Casalone R, Petri SL, Spada M, Gridelli B, Conaldi PG (2014) Isolation and characterization of multipotent cells from human fetal dermis. Cell Transplant 23:11691185

De Buys Roessingh AS, Hohlfeld J, Scaletta C, Hirt-Burri N, Gerber S, Hohlfeld P, Gebbers J-O, Applegate LA (2006) Development, characterization, and Use of a fetal skin cell bank for tissue engineering in wound healing. Cell Transplant 15:823-834

Dominici M, Le Blanc K, Mueller I, Slaper-Cortenbach I, Marini F, Krause D, Deans R, Keating A, Prockop D, Horwitz E (2006) Minimal criteria for defining multipotent mesenchymal stromal cells. The international society for cellular therapy position statement. Cytotherapy 8:315-317

Draaijers LJ, Tempelman FR, Botman YA, Tuinebreijer WE, Middelkoop E, Kreis RW, van Zuijlen PP (2004) The patient and observer scar assessment scale: a reliable and feasible tool for scar evaluation. Plast Reconstr Surg 113:1960-1965, discussion 1966-1967

Eggenhofer E, Luk F, Dahlke MH, Hoogduijn MJ (2014) The life and fate of mesenchymal stem cells. Front Immunol 5:148

Ferguson MW, Whitby DJ, Shah M, Armstrong J, Siebert JW, Longaker MT (1996) Scar formation: the spectral nature of fetal and adult wound repair. Plast Reconstr Surg 97:854-860

Glenn JD, Whartenby KA (2014) Mesenchymal stem cells: emerging mechanisms of immunomodulation and therapy. World J Stem Cells 6:526-539

Glenn JD, Smith MD, Calabresi PA, Whartenby KA (2014) Mesenchymal stem cells differentially modulate effector CD8+ T cell subsets and exacerbate experimental autoimmune encephalomyelitis. Stem Cells 32:2744-2755

Gnecchi M, Zhang ZP, Ni AG, Dzau VJ (2008) Paracrine mechanisms in adult stem cell signaling and therapy. Circ Res 103:1204-1219

Griffin MD, Ryan AE, Alagesan S, Lohan P, Treacy O, Ritter T (2013) Anti-donor immune responses elicited by allogeneic mesenchymal stem cells: what have we learned so far? Immunol Cell Biol 91:4051

Hass R, Kasper C, Bohm S, Jacobs R (2011) Different populations and sources of human mesenchymal stem cells (MSC): a comparison of adult and neonatal tissue-derived MSC. Cell Commun Signal 9:12

Hocking AM, Gibran NS (2010) Mesenchymal stem cells: paracrine signaling and differentiation during cutaneous wound repair. Exp Cell Res 316:2213-2219

Hohlfeld J, de Buys RA, Hirt-Burri N, Chaubert P, Gerber S, Scaletta C, Hohlfeld P, Applegate LA (2005) Tissue engineered fetal skin constructs for paediatric burns. Lancet 366:840-842

Hata K-I (2007) Current issues regarding skin substitutes using living cells as industrial materials. J Artif Organs 10:129-132

Kim W, Barron DA, San Martin R, Chan KS, Tran LL, Yang F, Ressler SJ, Rowley DR (2014) RUNX1 is essential for mesenchymal stem cell proliferation and myofibroblast differentiation. Proc Natl Acad Sci U S A 111:16389-16394

Kishi K, Okabe K, Shimizu R, Kubota Y (2012) Fetal skin possesses the ability to regenerate completely: complete regeneration of skin. Keio J Med 61:101-108

Klinger M, Marazzi M, Vigo D, Torre M (2008) Fat injection for cases of severe burn outcomes: a new perspective of scar remodeling and reduction. Aesthetic Plast Surg 32:465-469

Lamme EN, Van Leeuwen RTJ, Brandsma K, Van Marle J, Middelkoop E (2000) Higher numbers of autologous fibroblasts in an artificial dermal substitute improve tissue regeneration and modulate scar tissue formation. J Pathol 190:595-603

Lammers G, Verhaegen PD, Ulrich MM, Schalkwijk J, Middelkoop E, Weiland D, Nillesen ST, Van Kuppevelt TH, Daamen WF (2011) An overview of methods for the in vivo evaluation of tissue-engineered skin constructs. Tissue Eng Part B 17:33-55

Lataillade JJ, Doucet C, Bey E, Carsin H, Huet C, Clairand I, BottollierDepois JF, Chapel A, Ernou I, Gourven M, Boutin L, Hayden A, Carcamo C, Buglova E, Joussemet M, de Revel T, Gourmelon P (2007) New approach to radiation burn treatment by dosimetry- 
guided surgery combined with autologous mesenchymal stem cell therapy. Regen Med 2:785-794

Laverdet B, Micallef L, Lebreton C, Mollard J, Lataillade JJ, Coulomb B, Desmoulière A (2014) Use of mesenchymal stem cells for cutaneous repair and skin substitute elaboration. Pathol Biol 62:108-117

Le Blanc K (2003) Immunomodulatory effects of fetal and adult mesenchymal stem cells. Cytotherapy 5:485-489

Liu P, Deng Z, Han S, Liu T, Wen N, Lu W, Geng X, Huang S, Jin Y (2008) Tissue-engineered skin containing mesenchymal stem cells improves burn wounds. Artif Organs 32:925-931

Maxson S, Lopez EA, Yoo D, Danilkovitch-Miagkova A, LeRoux MA (2012) Concise review: role of mesenchymal stem cells in wound repair. Stem Cells Transl Med 1:142-149

Middelkoop E, van den Bogaerdt AJ, Lamme EN, Hoekstra MJ, Brandsma K, Ulrich MM (2004) Porcine wound models for skin substitution and burn treatment. Biomaterials 25:1559-1567

Mishra PJ, Banerjee D (2011) Activation and differentiation of mesenchymal stem cells. Methods Mol Biol 717:245-253

Nauta AJ, Westerhuis G, Kruisselbrink AB, Lurvink EG, Willemze R, Fibbe WE (2006) Donor-derived mesenchymal stem cells are immunogenic in an allogeneic host and stimulate donor graft rejection in a nonmyeloablative setting. Blood 108:2114-2120

Nuschke A (2014) Activity of mesenchymal stem cells in therapies for chronic skin wound healing. Organogenesis 10:29-37

Popova AP, Bozyk PD, Goldsmith AM, Linn MJ, Lei J, Bentley JK, Hershenson MB (2010) Autocrine production of TGF-betal promotes myofibroblastic differentiation of neonatal lung mesenchymal stem cells. Am J Physiol Lung Cell Mol Physiol 298:L735-743

Rasulov MF, Vasilchenkov AV, Onishchenko NA, Krasheninnikov ME, Kravchenko VI, Gorshenin TL, Pidtsan RE, Potapov IV (2005) First experience of the use bone marrow mesenchymal stem cells for the treatment of a patient with deep skin burns. Bull Exp Biol Med 139: $141-144$

Ren G, Zhang L, Zhao X, Xu G, Zhang Y, Roberts AI, Zhao RC, Shi Y (2008) Mesenchymal stem cell-mediated immunosuppression occurs via concerted action of chemokines and nitric oxide. Cell Stem Cell 2:141-150

Ren G, Su J, Zhang L, Zhao X, Ling W, L'Huillie A, Zhang J, Lu Y, Roberts AI, Ji W, Zhang H, Rabson AB, Shi Y (2009) Species variation in the mechanisms of mesenchymal stem cell-mediated immunosuppression. Stem Cells 27:1954-1962

Rigotti G, Marchi A, Galie M, Baroni G, Benati D, Krampera M, Pasini A, Sbarbati A (2007) Clinical treatment of radiotherapy tissue damage by lipoaspirate transplant: a healing process mediated by adipose-derived adult stem cells. Plast Reconstr Surg 119:14091422, discussion 1423-1404

Rolfe KJ, Grobbelaar AO (2012) A review of fetal scarless healing. ISRN Dermatol 698034

Ryan JM, Barry FP, Murphy JM, Mahon BP (2005) Mesenchymal stem cells avoid allogeneic rejection. J Inflamm (Lond) 2:8

Ryssel H, Gazyakan E, Germann G, Öhlbauer M (2008) The use of MatriDerm ${ }^{\circledR}$ in early excision and simultaneous autologous skin grafting in burns - a pilot study. Burns 34:93-97

Satish L, Kathju S (2010) Cellular and molecular characteristics of scarless versus fibrotic wound healing. Dermatol Res Pract 2010: 790234
Scott PG, Tredget EE (2005) Skin construct or biological bandage? Lancet 366:788-790

Sheng Z, Fu X, Cai S, Lei Y, Sun T, Bai X, Chen M (2009) Regeneration of functional sweat gland-like structures by transplanted differentiated bone marrow mesenchymal stem cells. Wound Repair Regen $17: 427-435$

Shi Y, Hu G, Su J, Li W, Chen Q, Shou P, Xu C, Chen X, Huang Y, Zhu Z, Huang X, Han X, Xie N, Ren G (2010) Mesenchymal stem cells: a new strategy for immunosuppression and tissue repair. Cell Res 20: $510-518$

Singer NG, Caplan AI (2011) Mesenchymal stem cells: mechanisms of inflammation. Annu Rev Pathol 6:457-478

Stoff A, Rivera AA, Sanjib Banerjee N, Moore ST, Michael Numnum T, Espinosa-de-Los-Monteros A, Richter DF, Siegal GP, Chow LT, Feldman D, Vasconez LO, Michael Mathis J, Stoff-Khalili MA, Curiel DT (2009) Promotion of incisional wound repair by human mesenchymal stem cell transplantation. Exp Dermatol 18:362-369

Tan KK, Salgado G, Connolly JE, Chan JK, Lane EB (2014) Characterization of fetal keratinocytes, showing enhanced stem cell-like properties: a potential source of cells for skin reconstruction. Stem Cell Rep 3:324-338

van den Bogaerdt AJ, van Zuijlen PP, van Galen M, Lamme EN, Middelkoop E (2002) The suitability of cells from different tissues for use in tissue-engineered skin substitutes. Arch Dermatol Res 294:135-142

van den Bogaerdt AJ, van der Veen VC, van Zuijlen PP, Reijnen L, Verkerk M, Bank RA, Middelkoop E, Ulrich MM (2009) Collagen cross-linking by adipose-derived mesenchymal stromal cells and scar-derived mesenchymal cells: are mesenchymal stromal cells involved in scar formation? Wound Repair Regen 17:548-558

van der Wal MB, Tuinebreijer WE, Bloemen MC, Verhaegen PD, Middelkoop E, van Zuijlen PP (2012) Rasch analysis of the Patient and Observer Scar Assessment Scale (POSAS) in burn scars. Qual Life Res 21:13-23

Wang Y, Chen X, Cao W, Shi Y (2014) Plasticity of mesenchymal stem cells in immunomodulation: pathological and therapeutic implications. Nat Immunol 15:1009-1016

Wisser D, Steffes J (2003) Skin replacement with a collagen based dermal substitute, autologous keratinocytes and fibroblasts in burn trauma. Burns 29:375-380

Xue L, Xu YB, Xie JL, Tang JM, Shu B, Chen L, Qi SH, Liu XS (2013) Effects of human bone marrow mesenchymal stem cells on burn injury healing in a mouse model. Int J Clin Exp Pathol 6:1327-1336

Yates CC, Hebda P, Wells A (2012) Skin wound healing and scarring: fetal wounds and regenerative restitution. Birth Defects Res C Embryo Today 96:325-333

Yoon BS, Moon JH, Jun EK, Kim J, Maeng I, Kim JS, Lee JH, Baik CS, Kim A, Cho KS, Lee HH, Whang KY, You S (2010) Secretory profiles and wound healing effects of human amniotic fluidderived mesenchymal stem cells. Stem Cells Dev 19:887-902

Young HE, Steele TA, Bray RA, Hudson J, Floyd JA, Hawkins K, Thomas K, Austin T, Edwards C, Cuzzourt J, Duenzl M, Lucas PA, Black AC Jr (2001) Human reserve pluripotent mesenchymal stem cells are present in the connective tissues of skeletal muscle and dermis derived from fetal, adult, and geriatric donors. Anat Rec 264: $51-62$ 